\title{
Obstructive sleep apnea (OSA) should be considered a comorbidity as a risk factor for COVID-19 fatality: A review. Part II
}

\author{
Leopoldo Rivera-Castaño* \\ Departamento de Neurología y Clínica del Sueño del Hospital Angeles Chihuahua, Chihuahua, Chihuahua, México
}

\begin{abstract}
The COVID-19 outbreak caused by the SARS-CoV-2 virus turned into a pandemic and from the first reported cases in December 2019-December 31, 2020, more than 82 million positive cases have been reported with a cumulative fatality of $1,806,155$ people due to the complication of a mild upper respiratory infection to a severe lower respiratory disease, such as acute respiratory distress syndrome, and death from multiple organ failure. Comorbidities such as obstructive sleep apnea (OSA) that have a high prevalence in older adults with obesity, should be considered as an additional risk factor for fatality, due to endothelial dysfunction secondary to hypoxia coupled with an increase in the inflammatory cascade with dysfunction of the glymphatic system during sleep in response to SARS-CoV-2.
\end{abstract}

Key words: OSA. COVID-19. Comorbidities. Risk factors.

\section{La apnea obstructiva del sueño (AOS) debería ser considerada una comorbilidad como factor de riesgo para la letalidad de COVID-19: revisión. Parte II}

\section{Resumen}

El brote de COVID-19 causado por el virus SARS-CoV-2 se convirtió en una pandemia y desde los primeros casos registrados en diciembre de 2019 hasta el 31 de diciembre de 2020, se han reportado más de 82 millones de casos positivos con una fatalidad acumulada de 1,806,155 personas debido a la complicación de una infección leve de las vías respiratorias superiores a una enfermedad grave de las vías respiratorias inferiores, como el síndrome de dificultad respiratoria aguda, y muerte por insuficiencia orgánica múltiple. Comorbilidades como la apnea obstructiva del sueño (AOS) que tienen una alta prevalencia en adultos mayores con obesidad, es un factor más de riesgo de letalidad, por la disfunción endotelial secundaria a la hipoxia aunada al incremento de la cascada inflamatoria con disfunción del sistema glinfático durante el sueño en respuesta al SARS-CoV-2.

Palabras clave: COVID-19. AOS. Comorbilidades. Factores de riesgo.

\section{Correspondence:}

*Leopoldo Rivera-Castaño

E-mail: drleopoldo.rivera@yahoo.com DOI: 10.24875/RMN.20000122
Date of reception: 24-11-2020

Date of acceptance: 11-03-2021

2604-6180/ @ 2021 Academia Mexicana de Neurología A.C. Published by Permanyer. This is an open access article under the CC BY-NC-ND license (http://creativecommons.org/licenses/by-nc-nd/4.0/).

Available online: 07-07-2021

\footnotetext{
Rev Mex Neuroci. 2021;22(4):159-172 www.revmexneurociencia.com
} 


\section{COVID-19. Neurological and neuropsychiatric manifestations and their neuropathology}

The most frequently reported neurological manifestations in patients infected with the SARS-CoV-2 coronavirus are headache (6\%-15\%), anosmia ( $41.0 \%)$, and ageusia (38.2\%). The headache is described as generalized, hemicranial, or occipital of the oppressive type and which increases with physical activity or head movements, characteristics suggesting valsalva effect and therefore cerebrospinal fluid flow dysfunction and periarterial and perivenous cerebral glymphatic system dysfunction $^{1-3}$

Deterioration of consciousness has been reported in up to $14.8 \%$ of cases of COVID-19 complicated with ARDS or Multiple Organ Dysfunction in the report by Mao et al., or as agitation in $69 \%$ of the cases and confusion in $45 \%$ of patients with post-intubation ARDS. Symptomatology that could correspond to delirium due to multiple causes: sedative drug effects, intubation with prolonged assisted ventilation, hypoxic, or metabolic encephalopathy ${ }^{4,5}$. Ischemic cerebrovascular disease has been reported in between $2.8 \%$ and $16.7 \%$, encephalopathy with epileptic seizures $0.5 \% .{ }^{6}$ Five cases of Guillain-Barre syndrome were reported among 1200 cases of patients with COVID-19 in Italy? In the United Kingdom out of 125 patients: cerebrovascular disease 57 (45.6\%) ischemic, 9 (7.2\%) hemorrhagic, 9 $(7.2 \%)$ unspecified encephalopathy, 7 (5.6\%) encephalitis, $10(8 \%)$ psychosis, $6(4.8 \%)$ neurocognitive disorder, and $4(3.2 \%)$ affective disorder ${ }^{8}$.

The presence of vasculitis/endotheliitis of small vessels with microhemorrhages and microinfarcts without damage to the large supra-aortic or intracerebral vessels has been reported in some cases (Figs. 1 and 2) ${ }^{9}$. However, two meta-analysis studies by stroke and COVID-19 report that elderly patients with elevated levels of D-dimer are associated with occlusion of the great vessels and increased mortality rates $^{10,11}$.

It is not yet clear whether SARS-CoV-2 is neurotropic in humans. Viral neuroinvasion could be achieved in a variety of ways, including trans-synaptic transfer through infected neurons, entry through the olfactory nerve, by the cribriform plate of the ethmoid bone to the glymphatic system with infection of astrocytes, infection of the vascular endothelium, or migration of leukocytes across the blood-brain barrier with manifestations of the central or peripheral nervous system (Table 1) 12-14.

\section{Incidence and mortality, by age and gender, of COVID-19}

According to the information provided by the WHO mission in China, from the first 41 cases reported between December 8, 2019, and January 2, 2020, it extended to 86,889 confirmed cases as of July 28,2020 , and 89,827 COVID-19 cases as of August 28, 2020. The median was 51 years of age with a majority of cases (77.8\%) between 30 and 69 years of age, $51 \%$ of these cases were male. On May 28, 2020, a worldwide pandemic was reported with $5,808,946$ and by June 28 , $10,115,912$ with 501,206 deaths, with a $6.4 \%$ fatality rate. On 28 July 2020, 16,662,462 positive cases were reported with 658,861 cumulative deaths and 24, 649, 431 COVID-19 cases as of August 28, with 835, 793 cumulative deaths. On September 28, 2020, were reported $33,034,598$ with 996,342 deaths and by October 28 were 44,481,667 positive COVID-19 cases with 1,172,086 cumulative deaths. A global of $82,777,305$ cases and 1,806,155 deaths were reported on December 31, 2020. In the Americas, the crisis has not yet reached its critical point, with the United States being the most affected country in the region and also in the world, since as of July 28,2020 , there were $4,347,717$ positive COVID-19 cases and 149,209 deaths reported, figure that increases to $11,715,316$ positive cases for COVID-19 with 252,535 deaths as of November 20, 2020 (Table 2). By December 31,2020 , the number of accumulated positive cases rose to $19,744,734$ and 342,395 people died ${ }^{15}$.

In Mexico, the first case of a person with imported COVID-19 was reported on February 28, 2020. The Mexican Ministry of Health and CONACYT (National Council for Science and Technology) reported on May 28, 2020: 81,400 confirmed cases of COVID-19 with 9044 deaths and in 1 month, June 28,2020, it almost tripled with 216,852 cases with 26,648 deaths. By July 28,2020 , there were 402,697 cases positive for COVID-19, 53.31\% male and $46.69 \%$ female, of which $72.37 \%$ were outpatient and $27.63 \%$ were hospitalized, reporting 44,876 cumulative deaths, predominantly male. On August 28 , 2020, 6 months after the first positive COVID-19 case in Mexico, were reported 585,738 confirmed cases, with a cumulative fatality of 63,146 people. On September 28 were reported 733,717 with 76,603 deaths, by October 28, 2020, were 906, 863 positive COVID-19 cases, with a cumulative deaths rate of 90,309 . On 20 November 2020, 1,025,969 cases, 51\% male and $48.94 \%$ female, with 100,823 deaths (Table 3). And as of December 31, 2020 , the total accumulated number of positive cases reported was 1,426,094 and 125,807 deaths ${ }^{16}$. 
Table 1. Neuropathogenesis and neurologic manifestations of the central or peripheral nervous system in positive COVID-19 patients

\begin{tabular}{|c|c|c|c|}
\hline Clinical entity & Signs and symptoms & Laboratory and cabinet & Pathogenesis \\
\hline Encephalopathy & Altered mental state & $\begin{array}{l}\text { MRI: Non-specific } \\
\text { EEG: Diffuse slowing } \\
\text { CSF: Normal } \\
\text { CSF SARS-CoV-2 RT-PCR: Negative }\end{array}$ & $\begin{array}{l}\text { Multiple Organ } \\
\text { Dysfunction. } \\
\text { Hypoxemia. Systemic } \\
\text { inflammation. } \\
\text { Endotheliitis }\end{array}$ \\
\hline Encephalitis & $\begin{array}{l}\text { Altered mental status and Central } \\
\text { Nervous System Dysfunction }\end{array}$ & $\begin{array}{l}\text { MRI: Non-specific } \\
\text { EEG: Diffuse and focal Slowing } \\
\text { CSF: Abnormal Pleocytosis }++\uparrow \text { Proteins } \\
\text { CSF SARS-CoV-2 RT-PCR: Negative }\end{array}$ & $\begin{array}{l}\text { Inflammation of the } \\
\text { Central Nervous } \\
\text { System }\end{array}$ \\
\hline Viral encephalitis & $\begin{array}{l}\text { Fever, altered mental status and } \\
\text { Central Nervous System Dysfunction }\end{array}$ & $\begin{array}{l}\text { MRI: Focal or multiple abnormalities } \\
\text { EEG: Diffuse and focal Slowing } \\
\text { CSF: Abnormal pleocytosis }++\uparrow \text { Proteins } \\
\text { CSF SARS-CoV-2 RT-PCR: Positive } \\
\text { Brain tissue: Positive Antigen or RNA }\end{array}$ & $\begin{array}{l}\text { Viral invasion to the } \\
\text { brain parenchyma }\end{array}$ \\
\hline Viral meningitis & $\begin{array}{l}\text { Fever, Headache with stiff neck, } \\
\text { Kernig/Brudzinski positive }\end{array}$ & $\begin{array}{l}\text { MRI: Non-specific } \\
\text { EEG: Normal or focal abnormal } \\
\text { CSF: Abnormal Pleocytosis }++\uparrow \text { Proteins } \\
\text { CSF SARS-CoV-2 RT-PCR: Positive }\end{array}$ & $\begin{array}{l}\text { Subarachnoid viral } \\
\text { invasion }\end{array}$ \\
\hline $\begin{array}{l}\text { Anosmia and/or } \\
\text { Augesia }\end{array}$ & Loss of smell/loss of taste & $\begin{array}{l}\text { Clinical tests for assessing smell and taste: } \\
\text { Abnormal }\end{array}$ & $\begin{array}{l}\text { Viral invasion, } \\
\text { peripheral or } \\
\text { central? }\end{array}$ \\
\hline $\begin{array}{l}\text { Cerebrovascular } \\
\text { disease }\end{array}$ & $\begin{array}{l}\text { Focal motor or sensory neurological } \\
\text { deficit }\end{array}$ & $\begin{array}{l}\text { MRI: Ischemia or hemorrhage Laboratory: } \\
\text { Increased markers of inflammation and } \\
\text { abnormal coagulation factors }\end{array}$ & Coagulopathy \\
\hline $\begin{array}{l}\text { Acute } \\
\text { disseminated } \\
\text { encephalomyelitis }\end{array}$ & $\begin{array}{l}\text { Headache, disorientation, acute } \\
\text { neurological deficit with psychiatric } \\
\text { manifestations }\end{array}$ & $\begin{array}{l}\text { MRI: Hyper intensive lesions in Flair with } \\
\text { supratentorial and subcortical predominance. } \\
\text { CSF: Normal or with } \uparrow \text { Proteins }\end{array}$ & Viral post-infection \\
\hline $\begin{array}{l}\text { Guillain-Barre } \\
\text { syndrome }\end{array}$ & $\begin{array}{l}\text { Ascending symmetrical flaccid muscle } \\
\text { weakness with areflexia and pain }\end{array}$ & $\begin{array}{l}\text { CSF: Cells } 0-5 \text { (Normal) }+\uparrow \text { Proteins } \\
\text { CSF SARS-CoV- } 2 \text { RT-PCR: Negative. Conduction } \\
\text { velocity and electromyography: Abnormal }\end{array}$ & Viral post-infection \\
\hline Muscular lesion & Myalgia & CPK: Elevated & $\begin{array}{l}\text { Myopathy or } \\
\text { Myositis? }\end{array}$ \\
\hline Encephalopathy & Altered mental state & $\begin{array}{l}\text { MRI: Non-specific } \\
\text { EEG: Diffuse slowing } \\
\text { CSF: Normal } \\
\text { CSF SARS-CoV-2 RT-PCR: Negative }\end{array}$ & $\begin{array}{l}\text { Multiple organ } \\
\text { dysfunction. } \\
\text { Hypoxemia. Systemic } \\
\text { inflammation. } \\
\text { Endotheliitis }\end{array}$ \\
\hline Encephalitis & $\begin{array}{l}\text { Altered mental status and Central } \\
\text { Nervous System Dysfunction }\end{array}$ & $\begin{array}{l}\text { MRI: Non-specific } \\
\text { EEG: Diffuse and focal slowing } \\
\text { CSF: Abnormal Pleocytosis }++\uparrow \text { Proteins } \\
\text { CSF SARS-CoV-2 RT-PCR: Negative }\end{array}$ & $\begin{array}{l}\text { Inflammation of the } \\
\text { Central Nervous } \\
\text { System. }\end{array}$ \\
\hline Viral encephalitis & $\begin{array}{l}\text { Fever, altered mental status and } \\
\text { Central Nervous System Dysfunction }\end{array}$ & $\begin{array}{l}\text { MRI: Focal or multiple abnormalities } \\
\text { EEG: Diffuse and focal slowing } \\
\text { CSF: Abnormal pleocytosis }++\uparrow \text { Proteins } \\
\text { CSF SARS-CoV-2 RT-PCR: Positive } \\
\text { Brain tissue: Positive antigen or RNA }\end{array}$ & $\begin{array}{l}\text { Viral invasion to the } \\
\text { brain parenchyma }\end{array}$ \\
\hline Viral meningitis & $\begin{array}{l}\text { Fever, Headache with stiff neck, } \\
\text { Kernig/Brudzinski positive }\end{array}$ & $\begin{array}{l}\text { MRI: Non-specific } \\
\text { EEG: Normal or focal abnormal } \\
\text { CSF: Abnormal pleocytosis }++\uparrow \text { Proteins } \\
\text { CSF SARS-CoV-2 RT-PCR: Positive }\end{array}$ & $\begin{array}{l}\text { Subarachnoid viral } \\
\text { invasion }\end{array}$ \\
\hline
\end{tabular}


Table 1. Neuropathogenesis and neurologic manifestations of the central or peripheral nervous system in positive COVID-19 patients (Continued)

\begin{tabular}{|l|l|l|l|}
\hline Clinical entity & Signs and symptoms & Laboratory and cabinet & Pathogenesis \\
\hline $\begin{array}{l}\text { Anosmia and/or } \\
\text { Augesia }\end{array}$ & Loss of smell/loss of taste. & $\begin{array}{l}\text { Clinical tests for assessing smell and taste: } \\
\text { Abnormal }\end{array}$ & $\begin{array}{l}\text { Viral invasion, } \\
\text { peripheral or } \\
\text { central? }\end{array}$ \\
\hline $\begin{array}{l}\text { Cerebrovascular } \\
\text { disease }\end{array}$ & $\begin{array}{l}\text { Focal motor or sensory neurological } \\
\text { deficit }\end{array}$ & $\begin{array}{l}\text { MRI: Ischemia or hemorrhage Laboratory: } \\
\text { Increased markers of inflammation and } \\
\text { abnormal coagulation factors }\end{array}$ & Coagulopathy \\
\hline $\begin{array}{l}\text { Acute } \\
\text { disseminated } \\
\text { encephalomyelitis }\end{array}$ & $\begin{array}{l}\text { Headache, disorientation, acute } \\
\text { neurological deficit with psychiatric } \\
\text { manifestations }\end{array}$ & $\begin{array}{l}\text { MRI: Hyper intensive lesions in Flair with } \\
\text { supratentorial and subcortical predominance. } \\
\text { CSF: Normal or with } \uparrow \text { Proteins }\end{array}$ & Viral post-infection \\
\hline $\begin{array}{l}\text { Guillain-Barre } \\
\text { syndrome }\end{array}$ & $\begin{array}{l}\text { Ascending symmetrical flaccid muscle } \\
\text { weakness with areflexia and pain }\end{array}$ & $\begin{array}{l}\text { CSF: Cells 0-5 (Normal) + } \uparrow \text { Proteins } \\
\text { CSF SARS-CoV-2 RT-PCR: Negative. Conduction } \\
\text { velocity and electromyography: Abnormal }\end{array}$ & Viral post-infection \\
\hline Muscular lesion & Myalgia & CPK: Elevated & Myopathy or \\
\hline
\end{tabular}

Table 2. COVID-19 Pandemic.

\begin{tabular}{|c|c|c|c|c|}
\hline Country & COVID-19 + Cases & Deaths & $\%$ & $C / 100,000$ \\
\hline $\begin{array}{l}\text { United } \\
\text { states of } \\
\text { America }\end{array}$ & $11,715,316$ & 252,535 & 2.15 & 77.19 \\
\hline India & $9,004,365$ & 132,162 & 1.46 & 9.77 \\
\hline Brazil & $5,981,767$ & 168,061 & 2.80 & 80.23 \\
\hline France & $2,137,096$ & 47, 201 & 2.20 & 70.46 \\
\hline Russia & $1,998,966$ & 34,525 & 1.72 & 23.90 \\
\hline Spain & $1,541,574$ & 42,291 & 2.74 & 23.79 \\
\hline $\begin{array}{l}\text { United } \\
\text { kingdom }\end{array}$ & $1,456,940$ & 53,870 & 3.69 & 81.02 \\
\hline Argentina & $1,349,434$ & 36,532 & 2.70 & 82.10 \\
\hline Italy & $1,308,528$ & 47,870 & 3.65 & 79.21 \\
\hline Colombia & $1,225,490$ & 34,761 & 2.83 & 70.01 \\
\hline Mexico & $1,019,543$ & 100,104 & 9.81 & 79.33 \\
\hline China & 91,935 & 4,742 & 5.15 & 0.34 \\
\hline
\end{tabular}

Global cases: 58, 014, 491. Global deaths: 1, 378, 866. Accumulated cases and deaths by country as of November 20, 2020.

\section{Risk factors for COVID-19 lethality}

The risk factors increase the possibility of Acute Respiratory Distress Syndrome (ARDS) and death for patients who are infected with the new coronavirus SARS-Cov-2 are:

\section{Age and Gender}

The number of COVID-19 positive patients who are asymptomatic is unknown, with percentages ranging from $3 \%$ to $6 \%$. Of the symptomatic patients, $26 \%$ have mild uncomplicated disease (Phase I), 65\% have moderate to severe symptoms (Phase II), and only $9 \%$ have severe symptoms that are complicated by pneumonia that progresses to ARDS or Multiple Organ Dysfunction (Phase III) (Table 4).

In multiple logistic regression, the male sex was associated with severe symptoms (odds ratio [OR] 25 [IC $\left.95 \% 11-6^{1}\right)$. The probability of severe symptoms increased slightly with age, although only people with 6069 years of age had a significantly higher risk compared to the baseline category, people with $50-59$ of age (OR 34 [95\% 1 4-9 ${ }^{5}$ ). Males accounted for $63.7 \%{ }^{17,18}$.

In Mexico, the reported case fatality as of June 28 , 2020 , represents $12.28 \%$ with 26,648 of the 216,852 positive COVID-19 cases. Males predominate with a $66 \%(17,569)$ versus a $34 \%(9,079)$ female. The age group of $92.65 \%$ is over 40 years of age. By July 28 , 2020 , the total number of cumulative deaths was 44,876, $64.94 \%$ male and $35.06 \%$ female. On August 28, 585,738 positive COVID-19 cases, 52.52\% men, $47.49 \%$ women, were reported with 63,146 deaths, $64.43 \%$ men, $35.57 \%$ women, with a rate per 1000 cases of 38.24-44.05 between 70 and 99 years of age, compared to 0.92 in those under 29 years of age, 76,603 deaths by September 28, 90,309 cumulative deaths by October 28, 2020, and 100,823 on November 20, 2020, 63.74\% male and $36.26 \%$ female (Fig. 3). 
Table 3. COVID-19 in Mexico. Cumulative cases and deaths from February 28, 2020 to November 20, 2020

\begin{tabular}{|c|c|c|c|c|c|}
\hline Ciudad de México & 184,636 & 16,770 & Sinaloa & 23,308 & 3,848 \\
\hline Estado de México & 104,341 & 11,443 & Guerrero & 23,112 & 2,335 \\
\hline Nuevo León & 61,545 & 4,384 & Yucatán & 22,931 & 2,005 \\
\hline Guanajuato & 55,967 & 3,730 & Durango & 18,212 & 1,017 \\
\hline Sonora & 41,118 & 3,340 & Querétaro & 17,804 & 1,369 \\
\hline Veracruz & 38,549 & 5,147 & Hidalgo & 17,638 & 2,543 \\
\hline Jalisco & 38288 & 4,568 & Quintana Róo & 13,992 & 1,885 \\
\hline Coahuila & 38,279 & 3,029 & Zacatecas & 13,828 & 1,159 \\
\hline Puebla & 38,215 & 5,037 & Baja California Sur & 13,684 & 650 \\
\hline Tabasco & 36,075 & 3,100 & Aguascalientes & 11,217 & 1,007 \\
\hline Tamaulipas & 34,014 & 2,917 & Tlaxcala & 8,872 & 1.193 \\
\hline San Luis Potosí & 32,267 & 2,308 & Chiapas & 7,657 & 1,088 \\
\hline Michoacán & 27,150 & 2,167 & Morelos & 7,404 & 1,271 \\
\hline Chihuahua & 26,974 & 3,035 & Nayarit & 6,997 & 911 \\
\hline Baja California & 24,840 & 4,098 & Colima & 6,963 & 785 \\
\hline Oахаса & 23,455 & 1,783 & Campeche & 6,673 & 901 \\
\hline Total & & & & $1,025,969$ & 100,823 \\
\hline
\end{tabular}

Table 4. Severity Levels and Evolution of COVID-19

\begin{tabular}{|c|c|}
\hline Severity levels and evolution & Clinical, laboratory and radiological findings \\
\hline $\begin{array}{l}\text { Phase I } \\
\text { - Uncomplicated disease }\end{array}$ & Fever, rhinorrhea, odynophagia, cough, myalgia, and headache \\
\hline $\begin{array}{l}\text { Phase II or pulmonary phase } \\
\text { - Mild pneumonia }\end{array}$ & Confirmed with chest X-ray or CT scan (CO-RADS 2-3). $\mathrm{SaO}_{2}>90 \%$. RT-PCR + \\
\hline - Severe pneumonia & $\begin{array}{l}\text { Severe pneumonia Fever, productive cough, dyspnea. Chest CT scan (CO-RADS } 4-5) \text {. } \\
\mathrm{SaO}_{2}<90 \% \text { and tachypnea } \geq 30 / \text { minute. RT-PCR }+\mathrm{IgM}+\text {, IgG }+ \\
\text { Lymphopenia }<0.8 \times 10^{9} / \mathrm{L} \text {. Thrombocytopenia }<100 \times 10^{9} / \mathrm{L} \text { D-dimer elevation }>1 \mu \mathrm{g} / \mathrm{L} \text {. PCR } \\
\text { elevation } \\
\text { Ferritin elevation }>300 \mu \mathrm{g} / \mathrm{L} \\
\mathrm{IL}-6 \text { elevation }>7.4 \mathrm{pg} / \mathrm{mL} \\
\text { Procalcitonin elevation } \geq 0.5 \mathrm{ng} / \mathrm{mL}\end{array}$ \\
\hline $\begin{array}{l}\text { Phase III or hyper-inflammatory phase } \\
\text { - Acute Respiratory Distress } \\
\text { Syndrome (ARDS) }\end{array}$ & $\begin{array}{l}\text { Cough, dyspnea. Chest CT with bilateral ground-glass opacities, with hypoxia: } \\
\text { - Mild: } 200 \mathrm{mmHg}<\mathrm{PaO}_{2} / \mathrm{FiO}_{2} \leq 300 \\
\text { - Moderate: } 100 \mathrm{mmH}<\mathrm{PaO}_{2} / \mathrm{FiO}_{2} \leq 200 \\
\text { - Severe: } \mathrm{PaO}_{2} / \mathrm{FiO}_{2} \leq 100 \mathrm{mmHg}\end{array}$ \\
\hline $\begin{array}{l}\text { - Multiple Organ Dysfunction } \\
\text { Syndrome by Septicemia }\end{array}$ & $\begin{array}{l}\text { Organic dysfunction on the SOFA Score }>2 \text { points or an acute change in the Quick Sofa } \\
\text { with }>2 \text { criteria }\end{array}$ \\
\hline - Septic shock & $\begin{array}{l}\text { Arterial hypotension that persists despite volume replacement with solutions and requires } \\
\text { vasopressors to maintain MAP } \geq 65 \mathrm{mmHg} \text { and lactate } \geq 2 \mathrm{moll} / \mathrm{L}(18 \mathrm{mg} / \mathrm{dL} \text { ) in the absence of } \\
\text { hypovolemia. }\end{array}$ \\
\hline
\end{tabular}



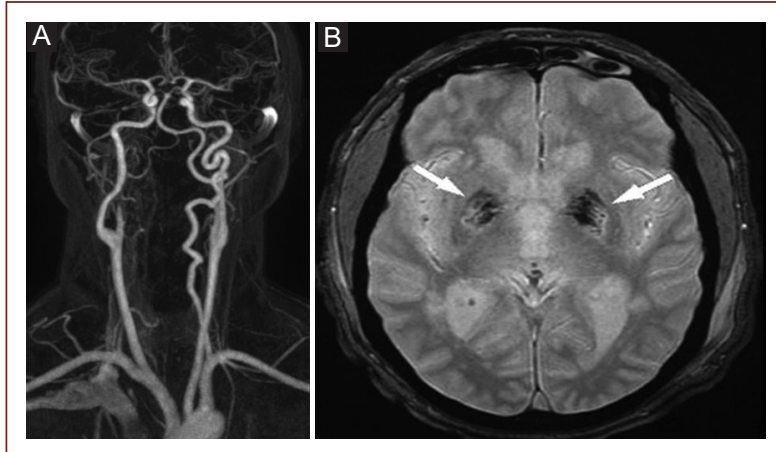

Figure 1. A: 3D coronal reconstruction of supraaortic and intracerebral vessels (B) T2 brain MRI with microhemorrhages in both pale globe.

2. Obesity, type 2 diabetes mellitus, and systemic arterial hypertension

An age of over 65 years and the male gender are risk factors for critical complication in patients infected with the new coronavirus SARS-CoV-2, but comorbidities also increase the risk of lethality in patients with COVID-19. Richardson et al. reported in 5700 patients in New York City, the presence of Arterial Hypertension in 3026 (56.6\%), Obesity with a Body Mass Index (BMI) greater than 35 in 1737 people (41.7\%), Diabetes mellitus in 1808 (33.8\%), and Sleep Apnea in only 154 patients $(2.9 \%) .{ }^{19}$ Out of a group of 124 people in France with COVID-19, 85 patients (68.6\%) required assisted mechanical ventilation (AMV), and the OR in cases requiring AMV with $\mathrm{BMI}>35 \mathrm{~kg} / \mathrm{m}^{2}$ versus patients with $\mathrm{BMl}<25 \mathrm{~kg} / \mathrm{m}^{2}$ was $7.36(95 \% \mathrm{Cl} 1.63-33.14)$ regardless of age, diabetes, or arterial hypertension ${ }^{20}$.

In Mexico, the Ministry of Health reports on November 20,2020, that in 1,025,969 positive cases for COVID- $19,51.06 \%$ were male and $48.94 \%$ female, arterial hypertension was in $20.09 \%$, obesity $19.59 \%$, diabetes mellitus $16.44 \%$, and smoking $7.77 \%$. In the critical group with the death of 100,823 people $(9.82 \%)$, $63.74 \%$ were of the male gender and $36.26 \%$ of the female gender, arterial hypertension was present in $45.38 \%$, diabetes mellitus in $38.58 \%$, obesity in $23.90 \%$, and smoking in $8.73 \%$ of the cases.

Bello-Chavolla et al. in a retrospective analysis of 15,529 SARS-Cov-2 positive patients compared to 46,960 SARS-Cov-2 negative persons found: obesity in $3,215(20.7 \%)$ versus $6,570(14 \%)$, respectively, arterial hypertension in $3,370(21.7 \%)$ versus $7353(15.7 \%)$, and diabetes mellitus in 2,831 (18.2\%) versus 5,163 (11\%). Considering that the coexistence of two
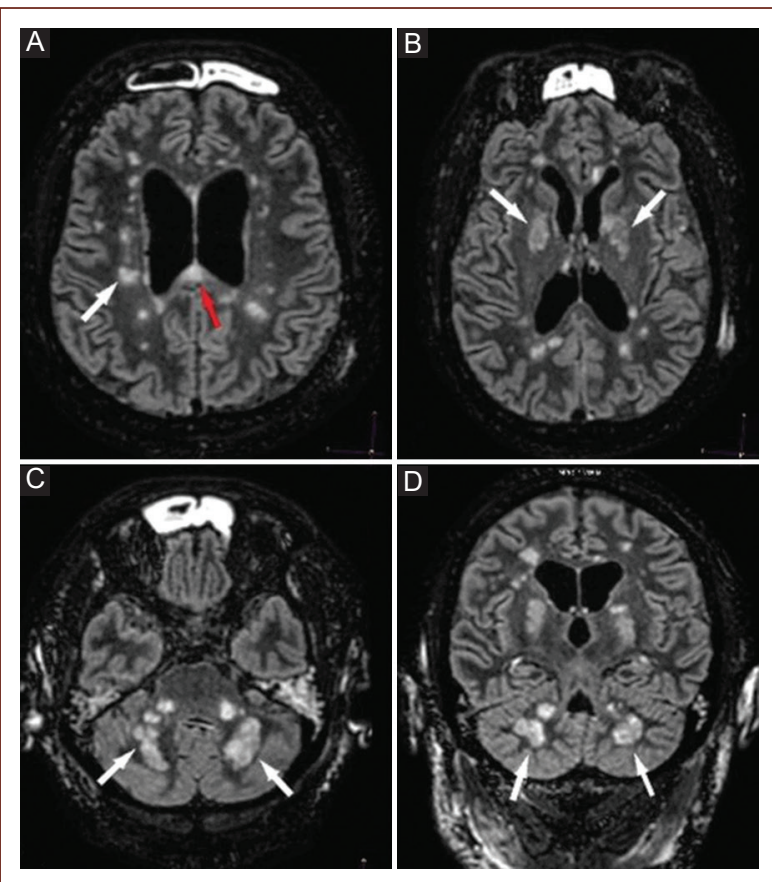

Figure 2. Axial (A, B, and C) and coronal (D) Flair MRI. Diffuse hyperintense images suggestive of ischemic lesions in basal ganglia and cerebellar peduncles.

comorbidities such as obesity and diabetes mellitus, particularly of early onset, increases the risk of severe complications in patients with COVID-19 (Fig. 4) ${ }^{21}$.

\section{Treatment of COVID-19}

The COVID-19 pandemic represents the largest global public health crisis of this generation and potentially since the outbreak of the pandemic influenza in 1918. The speed and volume of clinical trials launched to investigate possible therapies for COVID-19 highlight both the need and the ability to produce high-quality evidence even in the midst of a pandemic. Therapies have not been proven to be effective to this date and current prevention and treatment recommendations are very similar to those suggested in $1918^{22-24}$.

\section{Prevention}

Frequently washing hands with soap and water for at least $20 \mathrm{~s}$ or using $70 \%$ alcohol-based gel solutions. When coughing or sneezing, the use of sneeze etiquette, which consists of covering the nose and mouth with a tissue or the inside angle of the arm. No spitting, and if necessary, use a tissue, put it in a plastic bag, 


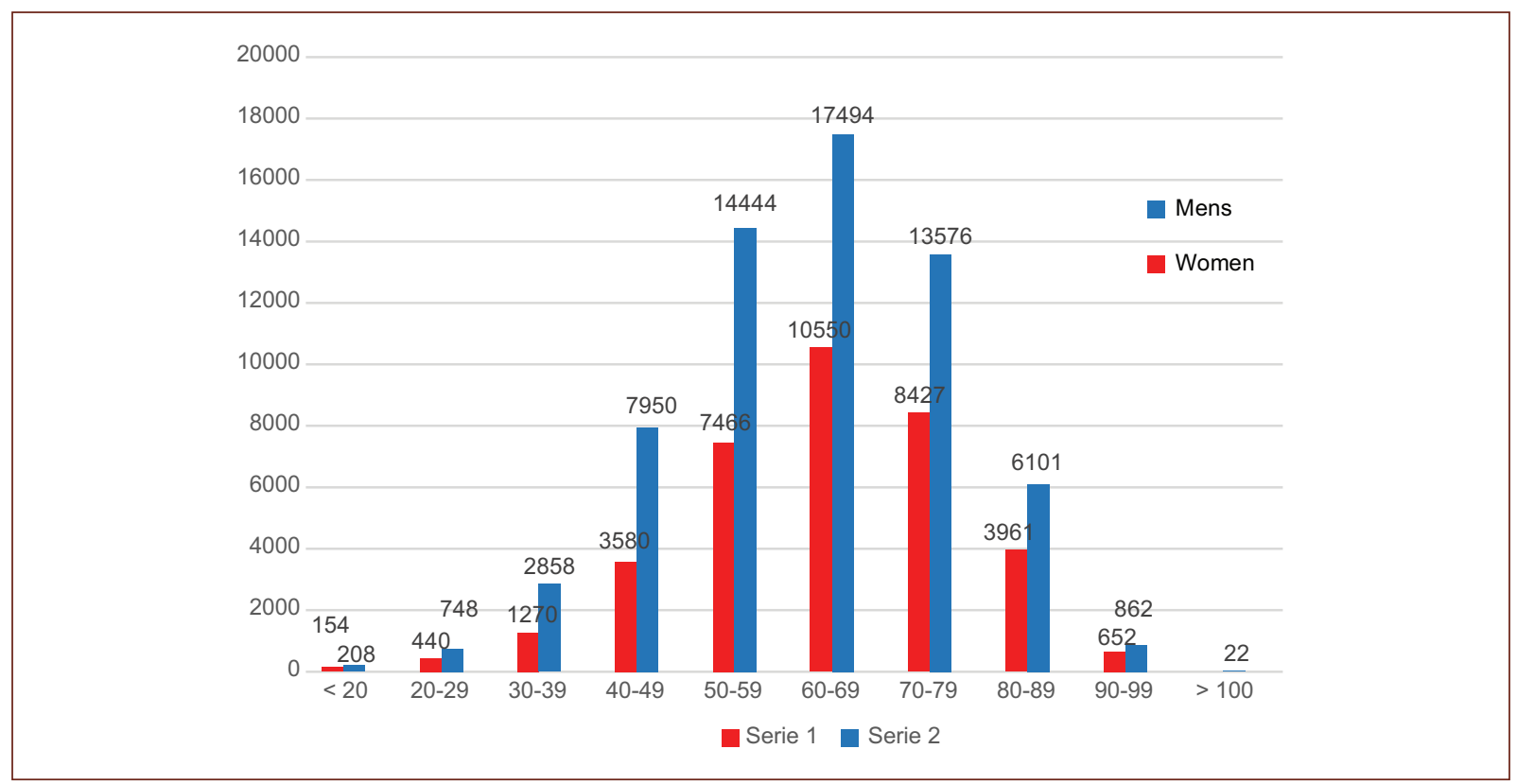

Figure 3. COVID-19 Mexico. Cumulative deaths by age and gender. Total: 100,823 February 28 to November 20, 2020.

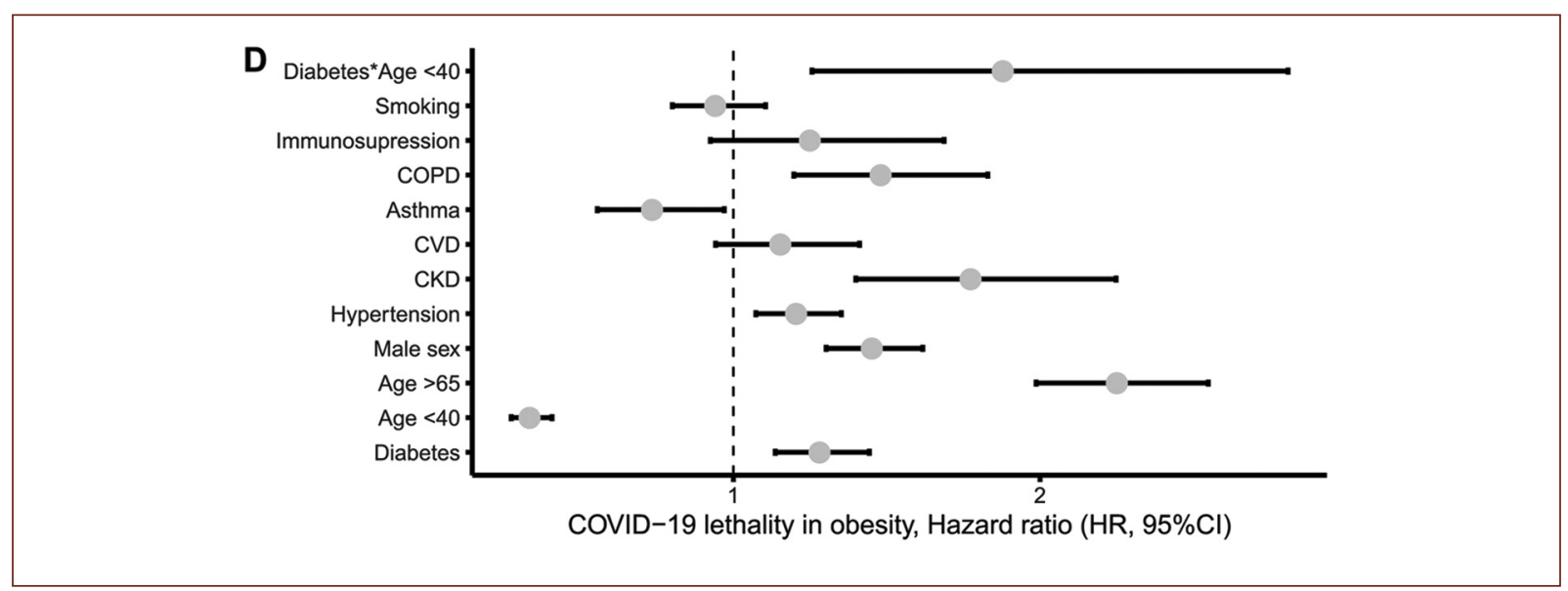

Figure 4. Comorbidities and Lethality of COVID-19 in Mexico (HR, 95\%Cl).

tie it up and throw it away, then wash hands. No face touching with dirty hands, especially the nose, mouth and eyes. Maintain a social distance of at least one meter. Clean and disinfect surfaces and objects of common use in houses, offices, closed spaces, transportation, meeting centers, etc., ventilating and allowing sunlight to enter. Staying at home, according to the health recommendations of each entity. Seek medical attention if any of the symptoms are present (fever over $38^{\circ} \mathrm{C}$, headache, sore throat, runny nose, etc.). Avoid contact as much as possible with people who have respiratory diseases. If you need to leave your home, wear a mask that covers your mouth and nose to reduce the risk of infection (Fig. 5). ${ }^{25}$ As of November 10, 2020, there are 11 vaccine study protocols for COVID-19 in phase III like that of the University of Oxford/Astra Zeneca. ${ }^{26}$ In December 2020, those of Biontech/Fosun Pharma/Pfizer and Moderna/NIAID were approved by the FDA. Pfizer's two-dose regimen vaccine (BNT12622b2) is a lipid nanoparticle-formulated, nucleoside-modified RNA vaccine that encodes a prefusion stabilized, membrane-anchored SARS CoV-2 fulllength spike protein that conferred $95 \%$ protection 


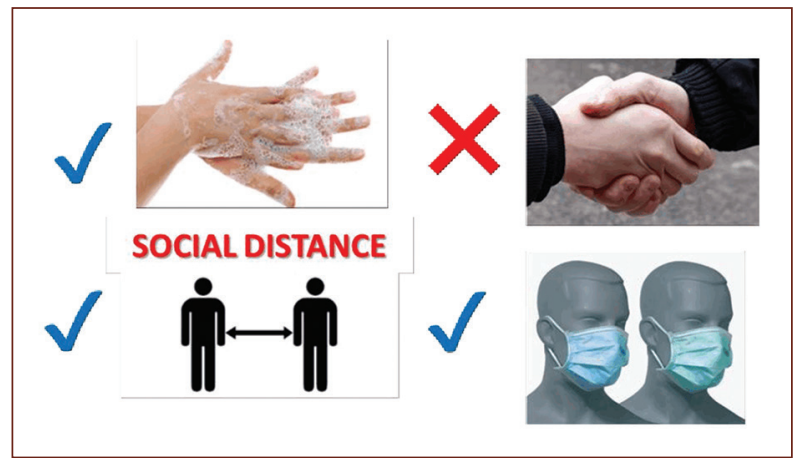

Figure 5. Recommendations on preventing SARS-CoV-2 infection, 2020.

against COVID-19 in persons 16 years of age or older ${ }^{27}$.

Convalescent plasma in the management of COVID-19 was not associated with a reduction in progression to severe COVID-19 or all-cause mortality (PLACID Trial) $^{28,29}$.

\section{Proposed pharmacological treatment}

Antimalarial drugs such as hydroxychloroquine and chloroquine have been proposed and showed some benefit in patients with SARS-CoV in 2002, (quinine was used in the 1918 influenza pandemic), protease inhibitor drugs such as lopinavir and ritonavir, RNA polymerase inhibitors such as remdesivir, ribavirin, or favipiravir, interferons such as the $B-1 b$ interferon, interleukin-6 (IL-6) receptor monoclonal antibody such as tocilizumab, interleukin-1(IL-1) receptor monoclonal antibody such as anakinra, drugs that prevent the introduction of SARS-CoV-2 to the host cell such as umifenovir (arbidol), and others such as nitazoxanide that induces the host cell's interferon response or an antiparasitic such as ivermectin with broad-spectrum antiviral activity ${ }^{30}$.

- The evidence on the effectiveness of chloroquine and hydroxychloroquine, in addition to being contradictory, is scarce and of low quality. One clinical trial reports that hydroxychloroquine decreases clinical recovery time by 2 days, while another reports no difference in viral clearance between patients receiving and not receiving the anti-malarial. $^{31}$ The included systematic reviews have contradictory conclusions, but all of them show the low quality of the evidence, one of these studies even published a retraction due to errors in the methodology 32 .
An important precaution is that the combined use of antimalarials with azithromycin, lopinavir/ritonavir, and remdesivir has been associated with an increased risk of a prolonged QTc interval and arrhythmias. Recently Geleris et al. report an observational study in New York that does not recommend the use of hydroxychloroquine in patients with COVID-19 complicated with ARDS ${ }^{33}$.

The evidence on antiviral therapy with lopinavir/ ritonavir, oseltamivir, and ganciclovir in patients with severe COVID-19 is weak and contradictory, and its effectiveness in decreasing the risk of progression to ARDS and reducing mortality is unclear. Drugs such as ivermectin and tocilizumab have low quality observational studies that do not allow us to assess the effectiveness and safety in patients with COVID-1934,35.

A recent double-blind controlled study of remdesivir against placebo reports a benefit in patients with COVID-19 in preventing a statistically significant percentage of ARDS complications by administering an initial dose of $200 \mathrm{mg}$ intravenous remdesivir and 100 mg every 24 h over the next 9 days ${ }^{36}$. However, a subsequent randomized study to evaluate the benefit of remdesivir showed no significant difference between remdesivir and placebo, evaluating results at day 5 and day 10 of treatment ${ }^{37}$, and the conclusions of the WHO SOLIDARITY study report that remdesivir, hydroxychloroquine, lopinavir, and interferon have little or no effect on hospitalized COVID-19 ${ }^{38}$.

Reyes et al. reported in December 2020 the use of colchicine $0.5 \mathrm{mg}$ orally per day, as a nonsteroidal anti-inflammatory therapy that inhibits E-selectin and L-selectin as well as NLRP3 preventing cytokine storm and platelet aggregation. The use of colchicine, in this randomized, double-blind study against placebo in COVID-19 positive patients, reduced the risk of hospitalization by $25 \%$, mechanical ventilation by $50 \%$, and death by $47 \% 39$.

- Two observational studies report beneficial effects of glucocorticoid use in patients with a serious COVID-19 disease and a systematic review and meta-analysis on clinical outcomes of the use of corticosteroid in patients with COVID-19 suggesting that its use at low or moderate doses reduces the possibility of mild/ moderate to severe disease progression, and mortality ${ }^{40-42}$.

- Both the Wuhan University guide and the Surviving Sepsis guidelines recommend oxygen therapy as needed according to hypoxia. It is recommended to start with a nasal cannula and progress to high flow oxygen sources. 


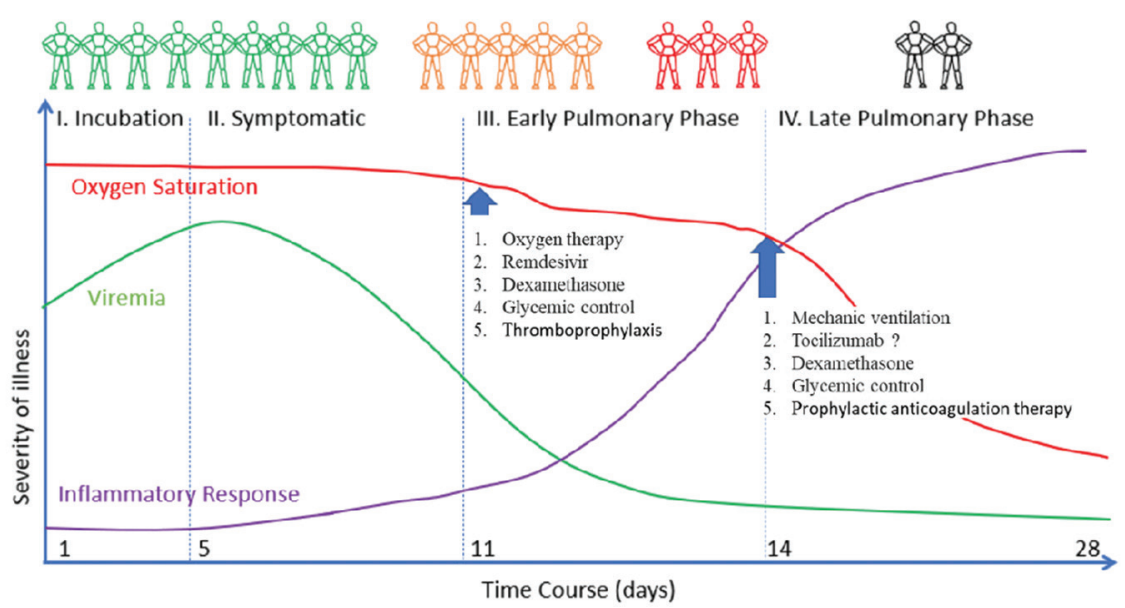

Figure 6. COVID-19. Evolution y proposed treatment.

- The two guidelines included recommend restrictive resuscitation with intravenous fluids (mainly crystalloids), both in ventilated and non-ventilated patients. The use in high volumes may worsen the degree of pulmonary edema, prolong days on the ventilator, ICU stay, and mortality in patients with ARDS. (Fig. 6) ${ }^{43,44}$.

It is clear that the pathogenesis of COVID-19 involves not only virus replication but also immunomodulation and inflammation. Sequential studies of biomarkers such as interleukin-6, C-reactive protein, ferritin, and D-dimer should help us to better understand the pathogenesis of COVID-19. Combination therapy studies with other antivirals and dexamethasone in appropriate sequence are a high priority, and plans for such studies are already underway.

Sleep associated breathing disorders such as obstructive sleep apnea syndrome (OSAS) and Sleep-Related Hypoventilation Syndromes have not been considered as risk factors in the complication of SARS-CoV-2 infection and that may contribute to the progression from a mild COVID-19 illness to a severe or critical phase with ARDS, including death.

\section{Adult Obstructive Sleep Apnea Syndrome}

Diagnostic criteria for OSAS in adults: Criteria A and $B$ must be met $^{45}$.

A) The presence of one or more of the following:

1. The patient complains of daytime sleepiness, non-restorative sleep, fatigue, or insomnia.

2. The patient wakes up due to shortness of breath, choking, or suffocation.
3. Bed partner reports habitual snoring and breathing pauses in the patient during sleep.

4. The patient has been diagnosed with arterial hypertension, presents mood disorders, cognitive dysfunction, coronary artery disease, ischemic cerebrovascular disease, congestive heart failure, atrial fibrillation, or type 2 diabetes mellitus.

B) The polysomnography (PSG) record shows (Fig. 7):

1. Five or more predominantly obstructive respiratory events (obstructive apnea, mixed apneas, hypopneas or respiratory effort related arousals [RERA] per hour of sleep during a PSG or hourly events performed outside a sleep clinic with limited number of channels).

Or:

C) PSG or monitoring (OCST: out of center sleep testing) demonstrates:

1. Fifteen or more predominantly obstructive respiratory events (apnea, hypopneas, and RERAs) per hour of sleep during a PSG or for $1 \mathrm{~h}$ of OCST monitoring.

Obstructive sleep apnea/hypopnea syndrome (OSAHS) is characterized by repeated episodes of complete (apnea) or partial (hypopnea) upper airway obstruction that occurs during sleep.

These events result in reduced blood oxygen saturation and usually end in brief, transitory awakenings. By definition, episodes of apnea or hypopnea last a minimum of $10 \mathrm{~s}$. Most events last from 10 to $30 \mathrm{~s}$, but sometimes they persist for a minute or more. These events can occur at any stage of sleep, but most often in stages N1, N2 of non-REM sleep, and R (REM sleep). During REM sleep or when the person is sleeping in 


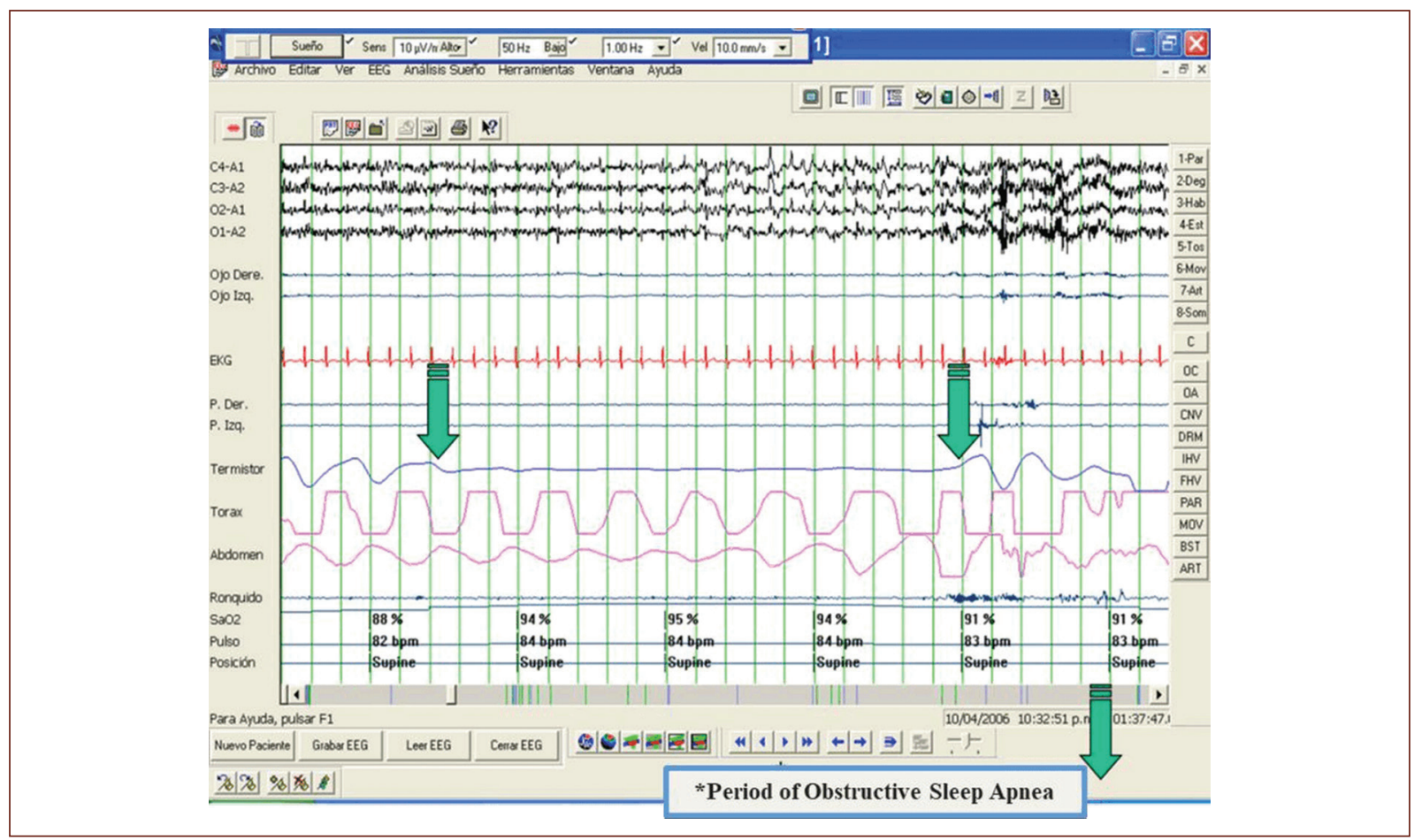

Figure 7. PSG of an obese adult patient, with controlled arterial hypertension, excessive daytime sleepiness, and loud snoring during sleep.

the supine position, events are usually longer and associated with a severe decrease in oxygen saturation.

Oxygen saturation usually returns to normal after normal breathing resumes, but may remain low if apnea or hypopnea events are very frequent and prolonged or if there is underlying lung disease. The prevalence of OSAHS has increased to $30 \%$ from 1990 to 2010 , from $4 \%$ in men and $2 \%$ in women to $7.5 \%$ in men and $4.2 \%$ in women. Age is also an important factor. As OSA is most common after age 40 and reaches its peak frequency in individuals over 60 years of age ${ }^{46}$.

Given that obesity is the main risk factor for the development of OSA, it is expected that as the Mexican population continues to suffer from the severe overweight pandemic considering the BMI (Body Mass Index $=$ mass $/$ height $^{2}=$ per $\mathrm{kg} / \mathrm{m}^{2}:$ BMl $\left.\mathrm{kg} / \mathrm{m}^{2}>25.00\right)$, obesity (BMI $\mathrm{kg} / \mathrm{m}^{2}>30.00$ ) and morbid obesity (BMI $\mathrm{kg} / \mathrm{m}^{2}>40.00$ ), the incidence and prevalence figures of OSA will also increase.

One parameter to consider in addition to $\mathrm{BMI}$ is the perimeter of the neck, as the larger the perimeter, the greater the risk of a higher apnea/hypopnea index (AHI) in people with OSAHS. That is, in women with a neck circumference greater than $38 \mathrm{~cm}$ and in men with more than $40 \mathrm{~cm}$, the frequency of OSA is higher in these subjects $^{47}$.

Hypoxia and the changes in sympathetic activity associated with OSA originate: insulin resistance with increased adipokines such as leptin and adiponectin related to pro-inflammatory cytokines such as interleukin-6 (IL-6), the monocyte chemoattractant protein (MCP-1), plasminogen activator inhibitor-1 (PAl-1), or tumor necrosis factor alpha (TNF $\alpha$ ), favoring endothelial dysfunction with systemic arterial hypertension, metabolic syndrome, coronary artery disease, or ischemic cerebrovascular disease ${ }^{48-50}$

Therefore, patients with OSAS have a higher risk of presenting these comorbidities, with an OR for arterial hypertension of 2.89 and for cerebrovascular disease the $\mathrm{OR}$ is of 1.58. On the other hand, the most frequent sleep disorder in post-cerebral infarction is OSA with a $62 \%$ on the first night ${ }^{51}$.

The general treatment for OSA is hygienic and dietary measures such as: weight loss, avoiding the use of tobacco, and alcohol or benzodiazepine abuse. Specific treatment is with CPAP (nasal continuous positive airway pressure) which lowers the apnea/hypopnea index $(\mathrm{AHI})$ and prevents chronic nocturnal hypoxemia with decreased superoxide production, and ROS, 


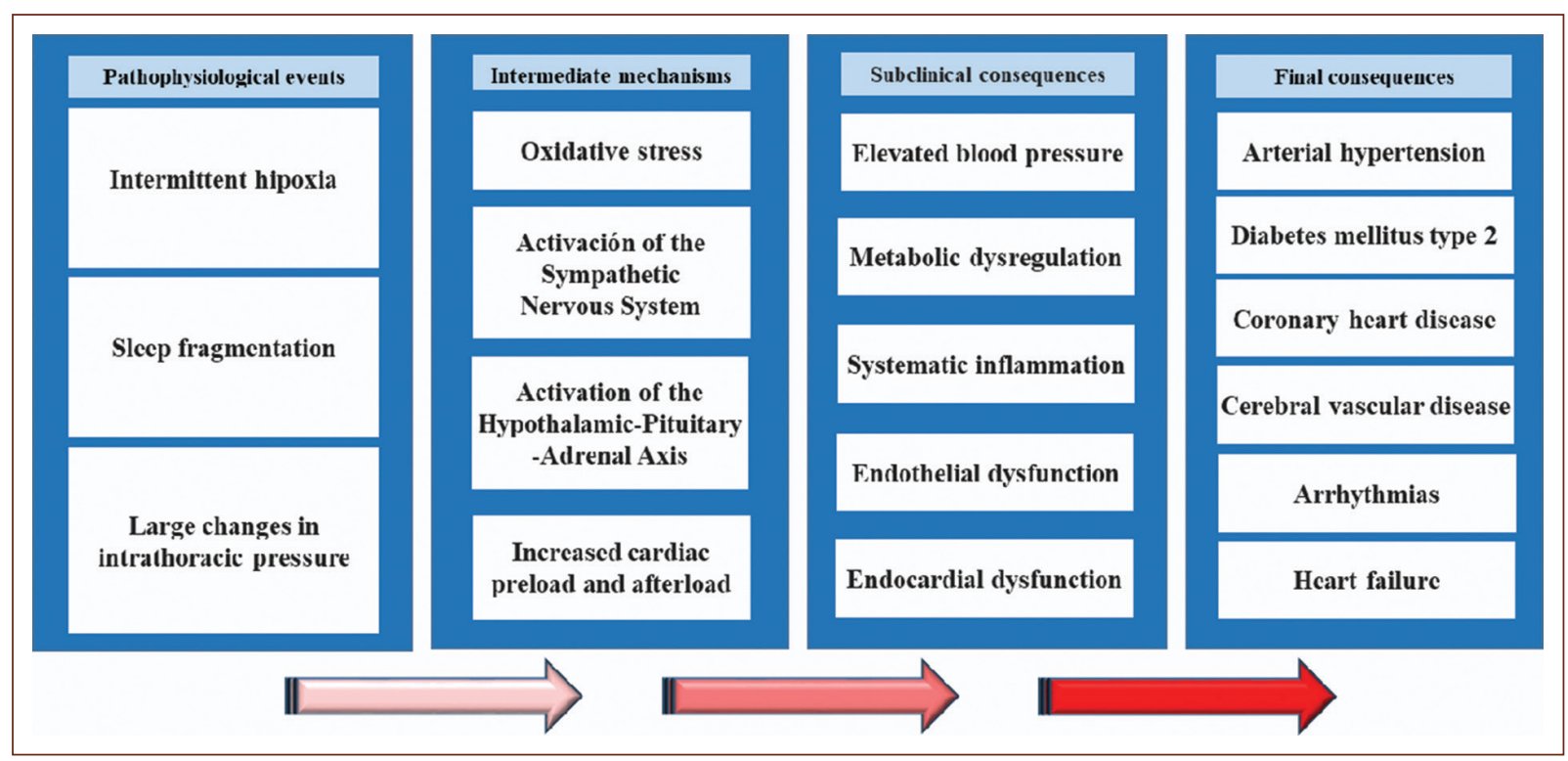

Figure 8. Putative causal mechanisms of metabolic and cardiovascular diseases related to obstructive sleep apnea (OSA).

decreasing endothelial adhesion molecules such as intercellular molecule-1 (ICAM-1), vascular cell adhesion molecule-1 (VCAM-1), interleukin-6 (IL-6), and increasing nitric oxide (NO) levels ${ }^{52}$.

\section{Obesity, OSAS, and Endothelial Dysfunction}

Endothelial and metabolic dysfunctions as well as adiposity constitute physiopathological links between an unfavorable lifestyle and the so-called classic and emerging risk factors, among which are arterial hypertension, dyslipidemia, diabetes mellitus, activation of the inflammatory cascade, the prothrombotic state, and a substrate that favors cardiac arrhythmias. Among the subclinical and final consequences the role of overweight and obesity stands out, which reflect visceral adiposity as a central element in the risk and pathogenesis of endothelial dysfunction leading to coronary artery disease, ischemic cerebrovascular disease, and most probably in the complication of COVID-19 favoring a hyperinflammatory reaction to the SARS-CoV-2 response and the immune response with pyroptosis and cytokine storm originating an increase in the exudate at alveolar level with vascular endotheliitis and pulmonary thrombosis (Fig. 8).

Visceral fat is considered a mere energy deposit with a wide anatomical distribution. In recent years, it has become clear that visceral fat tissue is a true endocrine organ of great activity producing adipokines that intervene in different events that can lead to the development of a metabolic syndrome. Insulin resistance is, for example, a key situation in the progression of the disease and different adipokines induce this resistance directly, such as leptin, resistin, TNF $\alpha$, and IL- 6 , by preventing the transduction of the signal produced by insulin, thus inhibiting the transcription and translocation of glucose receptors. The resulting hyperglycemia leads to an increase in the inflammatory process due to the production of reactive oxygen species (ROS) ${ }^{53,54}$ (Fig. 9).

At the same time, secondary hyperinsulinemia to such resistance causes defects in phagocytic cells by increasing the circulation of bacterial antigens, which have the capacity to activate leukocytes and adipocytes that then release pro-inflammatory cytokines, this being another causal mechanism of inflammation ${ }^{55-57}$.

Consequences will be increased in patients with COVID-19, if obesity is associated with OSAS or Sleep-Related Hypoventilation Syndromes (Fig. 10). At present, there is no direct evidence to support OSA as an independent risk factor for severe SARS-CoV-2 infection, but some inferences can be made from the data on ARDS. Obesity was shown to be an independent risk factor for developing ARDS among hospitalized patients. In a retrospective study of more than $6,000,000$ 


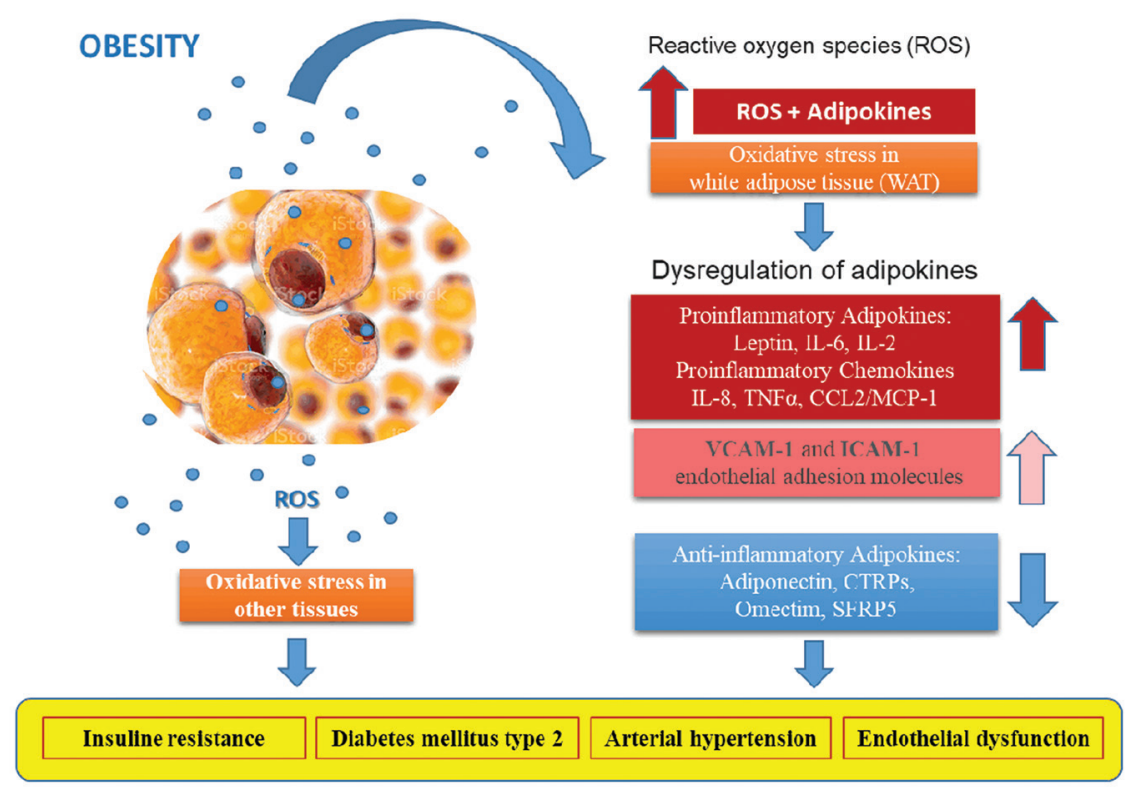

Figure 9. Increased oxidative stress in obesity.

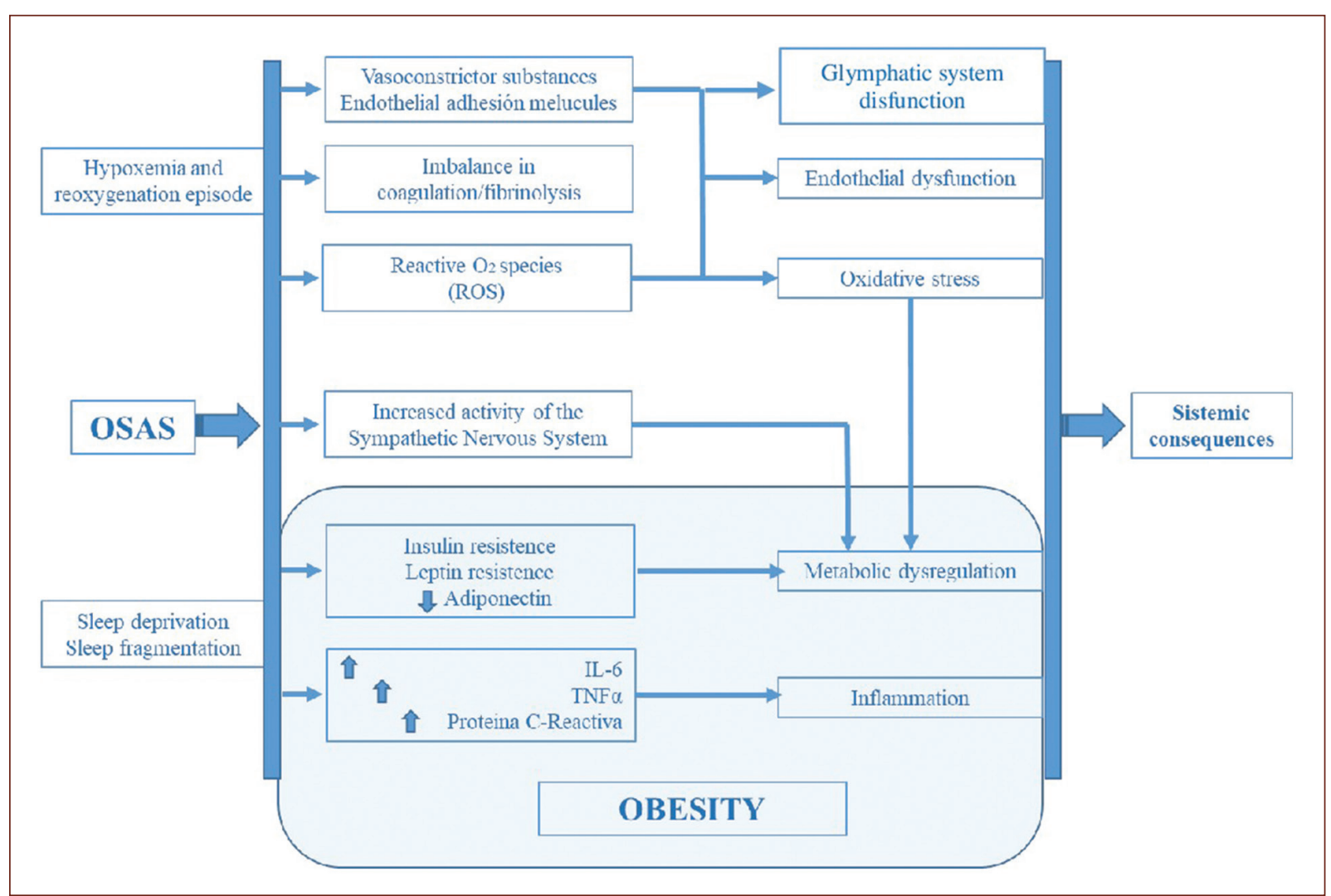

Figure 10. Consequences of the combination of OSAS with obesity. OSAS: Obstructive sleep apnea syndrome; ROS: reactive 02 species; TNF- $\alpha$ : tumor necrosis factor alfa. 
cases, obstructive sleep apnea has been associated with an increased risk of developing ARDS among patients undergoing surgical procedures. In addition, OSA patients who are hospitalized generally have an increased risk of mortality and morbidity, but the risk is decreased among patients treated with noninvasive ventilation (NIV) $)^{58,59}$.

\section{Conclusions}

Hypoxia due to inflammation of the upper airway or lower airway in patients infected by SARS-CoV-2, obesity with or without obstructive sleep apnea (OSA) in the elderly and OSA with dysfunction cerebral glymphatic system during sleep are severe factors that can contribute to the transition from phase I of COVID-19 to Phases II and III with hyperinflammation, acute respiratory distress syndrome (ARDS), multiple organ dysfunction syndrome, and death. We, therefore, consider the need to carry out prospective clinical studies supported by ambulatory polysomnography and in the shorter term, retrospective studies, to have information based on evidence medicine on the level of risk of OSA in comorbidity and fatality associated with COVID-19.

Hence, we propose to disseminate worldwide the need to question, in patients with initial COVID-19, the history of chronic snoring, the possibility of pauses in breathing during sleep reported by the patient's partner and the presence of excessive daytime sleepiness. Particularly in male patients over 60 years of age with obesity and/or diabetes, to have the clinical suspicion of OSA that can be corroborated with an outpatient polysomnography study and establish preventive treatment with colchicine as an anti-inflammatory measure and in case of increased frequency respiratory, dyspnea or $\mathrm{O} 2$ saturation less than $89 \%$, indicate the use of non-invasive ventilation, during wakefulness but with greater emphasis during sleep.

\section{Funding}

None.

\section{Conflicts of interest}

None.

\section{Ethical disclosures}

Protection of human and animal subjects. The authors declare that no experiments were performed on humans or animals for this study.
Confidentiality of data. The authors declare that they have followed the protocols of their work center on the publication of patient data.

Right to privacy and informed consent. The authors declare that no patient data appear in this article.

\section{References}

1. Porta-Etessam J, Matías-Guiu JA, González-García N, Gómez Iglesias P, Santos-Bueso E, Arriola-Villalobos P, et al. Spectrum of headaches associated with SARS-COV-2 infection: study of healthcare professionals. Headache. 2020;60:1697-704.

2. Agyeman $A A$, Chin $\mathrm{KL}$, Landersdorfer $\mathrm{CB}$, Liew $\mathrm{D}$ and Ofori-Asenso $\mathrm{R}$. Smell and taste dysfunction in patients with COVID-19: a systematic review and meta-analysis. Mayo Clin Proc. 2020;95:1621-31.

3. Hablitz LM, Plá V, Giannetto M, Vinitsky HS, Staeger FF, Metcalfe T, et al. Circadian control of brain glymphatic and lymphatic fluid flow. Nat Commun. 2020;11:4411.

4. Mao L, Jin H, Wang M, Hu Yu, Chen S, He Q, et al. Neurologic manifestations of hospitalized patients with coronavirus disease 2019 in Wuhan, China. JAMA Neurol. 2020;77:683-90.

5. Kotfis K, Williams Roberson S, Wilson JE, Dabrowski W, Pun BT, Ely EW. COVID-19: ICU delirium management during SARS-CoV-2 pandemic. Crit Care. 2020;24:176

6. Wang D, Hu B, Hu C, Zhu F, Liu X, Zhang J, et al. Clinical characteristics of 138 hospitalized patients with 2019 novel coronavirus-infected pneumonia in Wuhan, China. JAMA. 2020;323:1061-9.

7. Toscano G, Palmerini F, Ravaglia S, Ruiz L, Invernizzi P, Cuzzoni MA, et al. Guillain-Barré syndrome associated with SARS-CoV-2. N Engl $J$ Med. 2020;382:2574-6.

8. Varatharaj A, Thomas N, Ellul MA, Davies NWS, Pollak TA, Tenorio EL, et al. Neurological and neuropsychiatric complications of COVID-19 in 153 patients: a UK-wide surveillance study. Lancet Psychiatry. 2020:10:875-2.

9. Hanafi R, Roger PA, Perin B, Kuchcinski G, Deleval N, Dallery F, et al. COVID-19 neurologic complication with CNS vasculitis-like pattern. AJNR Am J Neuroradiol. 2020;41:1384-7.

10. Nannoni S, de Groot R, Bell S, Markus HS. Stroke in COVID-19: a systematic review and meta-analysis. Int J Stroke. 2021;16:137-49.

11. Yamakawa M, Kuno T, Mikami T, Takagi H and Gronseth G. Clinical characteristics of stroke with COVID-19: a systematic review and meta-analysis. J Stroke Cerebrovasc Dis. 2020;29:105288.

12. Zubair AS, McAlpine LS, Gardin T, Farhadian S, Kuruvilla DE, Spudich S. Neuropathogenesis and neurologic manifestations of the coronaviruses in the age of coronavirus disease 2019: a review. JAMA Neurol. 2020;77:1018-27.

13. Román GC, Spencer PS, Reis J, Buguet A, Faris ME, Katrak SM, et al. The neurology of COVID-19 revisited: a proposal from the Environmental Neurology Specialty Group of the World Federation of Neurology to implement international neurological registries. J Neurol Sci. 2020;414:116884.

14. Mestre $H$, Mori $X$, Nedergaard $M$. The brain's glymphatic system: current controversies. Trends Neurosci. 2020;43:458-66.

15. COVID-19 Map - Johns Hopkins Coronavirus Resource Center. Available from: https://www.coronavirus.jhu.edu/data. [Last accessed on 2020 Dec 31.

16. Información Internacional y Nacional Sobre Nuevo Coronavirus (COVID-2019), Secretaría de Salud. Available from: https://www.gob.mx/salud/documentos/informacion-internacional-y-nacional-sobre nuevo-coronavirus-2019-ncov. [Last accessed on 2020 Dec 31.

17. Wu C, Chen X, Cai Y, Xia J, Zhou X, Xu S, et al. Risk factors associated with acute respiratory distress syndrome and death in patients with coronavirus disease 2019 pneumonia in Wuhan, China. JAMA Intern Med. 2020;180:934-43.

18. Liang W, Liang H, Ou L, Chen B, Chen A, Li C, et al. Development and validation of a clinical risk score to predict the occurrence of critical illness in hospitalized patients with COVID-19. JAMA Intern Med. 2020;180:1081-9.

19. Richardson S, Hirsch JS, Narasimhan M, Crawford JM, McGinn T, Davidson KW, et al. Presenting characteristics, comorbidities, and outcomes among 5700 patients hospitalized with COVID-19 in the New York city area. JAMA. 2020;323:2052-9.

20. Simonnet A, Chetboun M, Poissy J, Raverdy V, Noulette J, Duhamel A et al. High prevalence of obesity in severe acute respiratory syndrome coronavirus-2 (SARS-CoV-2) requiring invasive mechanical ventilation. Obesity (Silver Spring). 2020;28:1195-9 
21. Bello-Chavolla OY, Bahena-López JP, Antonio-Villa NE, Vargas-Vázquez A, González-Díaz A, Márquez-Salinas A, et al. Predicting mortality due to SARS-CoV-2: a mechanistic score relating obesity and diabetes to $\mathrm{CO}$ VID-19 outcomes in Mexico. J Clin Endocrinol Metab. 2020;105:2752-61.

22. Bauchner H, Fontanarosa PB. Randomized clinical trials and COVID-19: managing expectations. JAMA. 2020;323:2262-3.

23. Márquez-Morfín L, Molina del Villar A. El otoño de 1918: las repercusiones de la pandemia de gripe en la ciudad de México. Desacatos. 2010;32:121 44.

24. Cuenya-Mateos MA. Reflexiones en torno a la pandemia de influenza de 1918. El caso de la ciudad de Puebla. Desacatos. 2010:32:145-58.

25. Clapp PW, Sickbert-Bennett E, Samet, JM, Berntsen J, Zeman KL, Anderson DJ, et al. Evaluation of cloth masks and modified procedure masks as personal protective equipment for the public during the $\mathrm{CO}$ VID-19 pandemic. JAMA Intern Med. 2020;181:463-9.

26. Ramasamy MN, Minassian AM, Ewer KJ, Flaxman AL, Folegatti PM Ewer KJ, et al. Safety and immunogenicity of ChAdOx1 nCoV-19 vaccine administered in a prime-boost regimen in young and old adults (COV002): a single-blind, randomised, controlled, phase 2/3 trial. Lancet. 2021;396:1979-93.

27. Polack FP, Thomas SJ, Kitchin N, Absalon J, Gurtman A, Lochart S, et al. Safety and efficacy of the BNT162b2 mRNA COVID-19 vaccine. N Engl J Med. 2020;383:2603-15.

28. Chai KL, Valk SJ, Piechotta V, Kimber C, Monsef I, Doree C, et al Convalescent plasma or hyperimmune immunoglobulin for people with COVID-19: a living systematic review. Cochrane Database Syst Rev. 2020;7:CD013600.

29. Agarwal A, Mukherjee A, Kumar G, Chatterjee P, Bhatnagar T, Malhotra P, PLACID Trial Collaborators. Convalescent plasma in the management of moderate covid-19 in adults in India: open label phase II multicentre randomised controlled trial (PLACID Trial). BMJ. 2020;371:m3939.

30. Marik P. EVMS Critical Care Covid-19 Management Protocol. Available from: https://www.evms.edu/covid-19/medical_information_resources. [Last accessed on 2020 May 11.

31. Gautret $P$, Lagier JC, Parola $P$, Hoang VT, Meddeb L, Mailhe M, et al. Hydroxychloroquine and azithromycin as a treatment of COVID-19: results of an open-label non-randomized clinical trial. Int $\mathrm{J}$ Antimicrob Agents. 2020;56:105949.

32. Mehra RM, Ruschitzka F, Patel AN. Retraction-hydroxychloroquine or chloroquine with or without a macrolide for treatment of COVID-19: a multinational registry analysis. Lancet. 2020;395:1820.

33. Geleris J, Sun Y, Platt J, Zucker J, Baldwin M, Hripcsak G, et al. Observational study of hydroxychloroquine in hospitalized patients with $\mathrm{Co}_{0}$ vid-19. N Engl J Med. 2020;382:2411-8.

34. Caly L, Druce JD, Catton MG, Jans DA, Wagstaff KM. The FDA-approved drug ivermectin inhibits the replication of SARS-CoV-2 in vitro. Antiviral Res. 2020;178:104787.

35. Somers EC, Eschenauer GA, Trosst JP, Golob JL, Gandhi TN, Wang L, et al. Tocilizumab for treatment of mechanically ventilated patients with COVID-19. Clin Infect Dis. 2020:ciaa954.

36. Beigel JH, Tomashek KM, Dodd LE, Mehta AK, Zingman BS, Kalil AC, et al. Remdesivir for the treatment of Covid-19 - preliminary report. $\mathrm{N}$ Engl J Med. 2020;383:993-4.

37. Goldman JD, Lye D, Hui DS, Marks KM, Bruno R, Montejano R, et al. Remdesivir for 5 or 10 days in patients with severe Covid-19. N Engl J Med. 2020;383:1827-37.

38. Pan H, Peto R, Henao-Restrepo M, Preziosi MP, Sathiyamoorthy V, Karim QA, et al. Repurposed antiviral drugs for COVID-19 - interim WHO solidarity trial results. N Eng J Med. 2020;384:497-511.
39. Mahase E. COVID-19: low dose steroid cuts death in ventilated patients by one third, trial finds. BMJ. 2020;369:m2422.

40. Horby P, Lim WS, Emberson JR, Mafham M, Bell JL, Linsell L, et al. Dexamethasone in hospitalized patients with COVID-19. N Engl J Med. 2021;384:693-704

41. Shuto H, Komiya K, Yamasue M, Uchida S, Ogura T, Mukae H, et al. A systematic review of corticosteroid treatment for noncritically ill patients with COVID-19. Sci Rep. 2020;10:20395.

42. Sanders JM, Monogue ML, Jodlowski TZ, Cutrell JB. Pharmacologic treatments for coronavirus disease 2019 (COVID-19): a review. JAMA. 2020;323:1824-36

43. Vélez M, Vélez V, Marín IC, Castaño $D$, Velázquez-Salazar $P$, Vera-Giraldo CY, et al. Pharmacological Interventions for Adults with COVID-19 Infection: Rapid Synthesis (Up to date). Available from: https://www.es.cochrane.org/sites/es.cochrane.org/files/public/ uploads/COVID-19/udea-uned rapissynthesis_covid19_ncov19_treatment_06abril2020.pdf.

44. American Academy of Sleep Medicine. International Classification of Sleep Disorders. $3^{\text {rd }}$ ed. Darien, Illinois: American Academy of Sleep Medicine; 2014.

45. Peppard PE, Young T, Barnet JH, Palta M, Hagen EW, Hla KM. Increased prevalence of sleep-disordered breathing in adults. Am J Epidemiol. 2013;177:1006-14

46. Valencia-Flores M, Rebollar-González V, Orea-Tejeda A, Castaño-Meneses A, García-Ramos G, González-Barranco J. Apnea del sueño en el paciente obeso. Rev Endocrinol Nutr. 2001;9:97-102.

47. Imayama I, Prasad B. Role of leptin in obstructive sleep apnea. Ann Am Thorac Soc. 2017;14:1607-21.

48. Bohórquez-Rivero JJ, Rivera-Moreno MM, Rivera-Moreno E, Alvear-Orózco AS, Lavalle-Jiménez CM. Leptina y su participación en la enfermedad arterial coronaria. Arch Med. 2020;16:3.

49. Jehan S, Farag M, Zizi F, Pandi-Perumal SR, Chung A, Truong A, et al. Obstructive sleep apnea and stroke. Sleep Med Disord. 2018:2:120-5.

50. González-Aquines A, Martínez-Roque D, Treviño-Herrera AB, Chávez-Luevanos BE, Guerrero-Campos F, Góngora-Rivera F. Síndrome de apnea obstructiva del sueño y su relación con el ictus isquémico. Rev Neurol. 2019;69:255-60.

51. Gottlieb DJ, Punjabi NM. Diagnosis and management of obstructive sleep apnea: a review. JAMA. 2020;323:1389-400.

52. Vega-Robledo GB, Rico-Rosillo MG. Tejido adiposo: función inmune y alteraciones inducidas por obesidad. Rev Alerg Mex. 2019;66:340-53.

53. Carvajal-Carvajal C. Especies reactivas del oxígeno: formación, función y estrés oxidativo. Med Legal Costa Rica. 2019;36:91-100.

54. Robles-Vera I, Toral M, de la Visitación N, Aguilera-Sànchez N, Redondo JM, Duarte J. Protective effects of short-chain fatty acids on endothelial dysfunction induced by angiotensin II. Front Physiol. 2020;11:277.

55. Campos-Codo A, Gastão-Davanzo G, de Brito-Monteiro L, Fabiano de Souza G, Primon-Muraro S, Virgilio-da-Silva JA, et al. Elevated glucose levels favor SARS-CoV-2 infection and monocyte response through a HIF-1 $\alpha /$ glycolysis-dependent axis. Cell Metab. 2020;32:437-46.

56. Wu MF, Chen YH, Chen HC, Huang WC. Interactions among obstructive sleep apnea syndrome severity, sex, and obesity on circulatory inflammatory biomarkers in patients with suspected obstructive sleep apnea syndrome: a retrospective, cross-sectional study. Int J Environ Res Public Health. 2020;17:4701. 